\title{
Host mediated anti-tumor effect of oncolytic Newcastle disease virus after locoregional application
}

\author{
LEONIDAS APOSTOLIDIS, VOLKER SCHIRRMACHER and PHILIPPE FOURNIER \\ German Cancer Research Center, Division of Cellular Immunology, \\ Im Neuenheimer Feld 280, D-69120 Heidelberg, Germany
}

Received March 23, 2007; Accepted May 21, 2007

\begin{abstract}
Several strains of the Newcastle disease virus (NDV) have raised considerable interest in recent years for clinical application because of their oncolytic properties. In this study we characterized virological, immunological and anti-tumor properties of some NDV strains. The oncolytic strain $M T H-68 / H$ was the most potent interferon- $\alpha$ inducer and, after UV light inactivation, it was the only tested NDV strain which induced in human PBMC anti-tumor activity in vitro. Upon systemic application to mice bearing a virus susceptible intradermal tumor, no significant anti-tumor effects were observed with the two oncolytic strains Italian and $M T H-68 / H$ while the treatment had significant side effects as seen by loss of body weight. In contrast, when using a locoregional application model for treatment of liver metastases of luciferase transfected CT26 colon carcinoma cells, $M T H-68 / H$ showed a significant delay in tumor growth, as well as prolonged survival but no effects on body weight. Surprisingly, this CT26 murine tumor cell transfectant was resistant in vitro to virus infection and oncolysis. These results suggest: i) that locoregional application of oncolytic NDV is more effective than systemic i.v. application; and ii) that oncolytic NDV can mediate effects even against a virusresistant tumor line. The involvement of host anti-tumor immune responses as an important mechanism in therapies based on oncolytic NDV will be discussed.
\end{abstract}

\section{Introduction}

Oncolytic viruses have raised considerable interest as vectors for treatment of human tumors in recent years $(1,2)$. One of these viruses, the avian paramyxovirus NDV has been reported to have anti-neoplastic (3) as well as immune stimulating properties $(4,5)$. Depending on their virulence, different NDV strains are classified as either lentogenic, mesogenic or velo-

Correspondence to: Dr Philippe Fournier, German Cancer Research Center (DKFZ), Division of Cellular Immunology, D010, Im Neuenheimer Feld 280, D-69120 Heidelberg, Germany

E-mail: p.fournier@dkfz.de

Key words: Newcastle disease virus, oncolytic, systemic, locoregional, immunostimulatory genic but they can not be distinguished by serotypes (6). An important factor that influences the virulence is determined by the cleavage site of the F-gene (7). Some virulent NDV strains are also oncolytic (8-10) and attenuated strains thereof have been applied to cancer patients. While all strains of NDV appear to show tumor selectivity of replication in mouse and human cells $(11,12)$, lentogenic strains show a monocyclic replication behaviour while the more virulent strains show multicyclic replication (13). We used the lentogenic strain Ulster to infect human tumor cells for preparation of the autologous virus modified tumor vaccine ATV-NDV (14). Postoperative vaccination of cancer patients with this vaccine had beneficial effects on long-term survival (15). This was true even for very aggressive tumors refractory to standard treatments, such as glioblastoma and head and neck squamous cell carcinoma $(16,17)$.

Much interest has recently been raised in the NDV variant $M T H-68 / H$ that was generated by several passages in chicken embryos of the original Hertfortshire strain of NDV designated Herz'33 (18). It was reported to have oncolytic capacity and in vivo anti-tumor activity (19). A recent in vitro study provided evidence that $M T H-68 / H$ kills tumor cells by inducing endoplasmic reticulum stress leading to p53 independent apoptotic cell death (20). In view of our positive results with the ATV-NDV vaccine and the known immune stimulatory properties of $\operatorname{NDV}(21,22)$, the question arose whether the antitumor effects of oncolytic NDV strains are entirely due to direct antitumor effects of the virus as suggested (20) or may also involve host-mediated anti-tumor mechanisms.

To investigate this question we have performed a comparative analysis of various NDV strains and tested in vitro and in vivo direct and host mediated anti-tumor effects. We will show that the oncolytic strain $M T H-68 / H$ induces the strongest interferon- $\alpha$ response in human PBMC. Host mediated anti-tumor effects were tested with a mouse tumor cell line that was resistant to the oncolytic effects of this virus. Our findings suggest that oncolytic NDV strains can induce strong host mediated anti-tumor activity.

\section{Materials and methods}

Cells and viruses. QM5 cells (kindly provided by Dr P. Antin, University of Arizona, AZ) were propagated in medium 199 supplemented with $10 \%$ fetal calf serum (FCS) and $10 \%$ 
tryptose phosphate broth. Human breast carcinoma MCF7, human cervix carcinoma HeLa cells and the continuous African Green Monkey kidney Vero cells were grown in Dulbecco's modified Eagle's medium (DMEM) supplemented with $10 \%$ FCS. Eb-M7 cells were propagated in RPMI-1640 supplemented with $10 \%$ FCS, ESb-MP cells in RPMI-1640 with $10 \%$ FCS and $0.05 \mathrm{mM}$ B-mercaptoethanol. CT26-Luc cells were kindly provided Dr O. van Tellingen (The Netherlands Cancer Research Institute, Amsterdam, The Netherlands). These cells were obtained by transfection of the CT26 cell line provided by Dr I.J. Fidler (Department of Cell Biology, University of Texas, M.D. Anderson Cancer Center, Houston, TX) with a plasmid coding for the firefly luciferase gene. They were grown in minimal essential medium (MEM) supplied with 10\% FCS, MEM non-essential amino acids and sodium pyruvate. Incubation was performed at $37^{\circ} \mathrm{C}$ in humidified atmosphere of $5 \% \mathrm{CO}_{2}$. All reagents were purchased from Gibco Life Technologies (Karlsruhe, Germany). Peripheral blood mononuclear cells (PBMC) were purified from buffy coats of healthy donors via Ficoll centrifugation.

NDV Ulster was obtained in 1984 from Dr P.H. Russel (University London, UK). NDV Italian was obtained in 1986 from Dr H.D. Klenk (University Giessen, Germany). Recombinant NDFLtag-EGFP (23) that was generated from a cDNA clone of NDV LaSota by inserting the EGFP gene as reporter gene and by modifying the sequence of the cleavage site of the F protein so that the virus could replicate in a multicyclic fashion in tumor cells, was kindly provided by Dr B. Peeters (Animal Sciences Group, Wageningen University and Research Centre, Division of Infectious Diseases, Lelystad, The Netherlands). NDV MTH-68/H was kindly provided by Dr G. Noss (Malsch, Germany). The viruses were propagated in embryonated chicken eggs, harvested from the allantoic fluid and purified by ultracentrifugation as described previously (24). However, for MTH-68/H a sucrose concentration of $50 \%(\mathrm{w} / \mathrm{w})$ was used. Aliquots were cryopreserved at $-70^{\circ} \mathrm{C}$. Quantification was performed by hemagglutination assay. The smallest virus concentration leading to visible agglutination of sheep erythrocytes is defined as 1 hemagglutination unit (HU). UV inactivation of NDV was done for $5 \mathrm{~min}$ as described (24).

Virus dilution endpoint assay. Vero cells were seeded at a concentration into 96-well plates at a concentration of 50,000 cells per well. When they reached confluency, NDV strains were serially diluted in culture medium and added to the Vero cell monolayer starting with dose of $50 \mathrm{HU}$ per well. After a 6-day incubation in $5 \% \mathrm{CO}_{2}$ atmosphere at $37^{\circ} \mathrm{C}$ the medium was removed and crystal violet added to the wells. After $30 \mathrm{~min}$ at $37^{\circ} \mathrm{C}$ the crystal violet was removed by aspiration and cell lysis could be seen. The tissue culture infectivity dose of $50 \%\left(\mathrm{TCID}_{50}\right)$ was determined according to the Reed and Münch formula (25).

Quantification of the $M$ gene and melting curve analysis of the $F$ gene by real-time reverse transcriptase PCR (RRT$P C R)$. RNA was extracted from virus suspension via the QIAamp ${ }^{\circledR}$ Viral RNA kit (Qiagen GmbH, Hilden, Germany). cDNA was then synthesized using SuperScript II RNase
H-reverse transcriptase (Invitrogen, Karlsruhe, Germany) and random hexamers. RRT-PCR reactions were performed on a GeneAmp ${ }^{\circledR} 5700$ sequence detection system (Applied Biosystems GmbH, Weiterstadt, Germany), all primers and probes were synthesized by MWG-Biotech AG (Munich, Germany).

For absolute quantification of the M gene, RRT-PCR was performed in a $25 \mu \mathrm{l}$ reaction mixture containing $18.5 \mu \mathrm{l}$ master mix (qPCR Core Kit, Eurogentec, Liege, Belgium), $300 \mathrm{nM}$ of each primer for the $\mathrm{M}$ gene (sense 5'-AGT GAT GTG CTC GGA CCT TC-3', antisense 5'-CCT GAG GAG AGG CAT TTG CTA-3') and $100 \mathrm{nM}$ probe for the $\mathrm{M}$ gene [5'-(FAM) TTC TCT AGC AGT GGG ACA GCC TGC (TAMRA)-3'] (as described in ref. 26). The samples were dilutions of viral cDNA or of a plasmid containing the $\mathrm{M}$ gene, named PCI-Neo-M (kindly provided by Dr B. Peeters). A common threshold was set during the exponential amplification period to determine a specific threshold cycle $\left(\mathrm{C}_{\mathrm{T}}\right)$ for each sample. By correlating the $\mathrm{C}_{\mathrm{T}}$ values with the HU titer initially used for RNA-extraction on the one hand and with the copy number of the M-plasmid on the other hand, M gene copy number per HU could be determined.

For melting curve analysis of the $\mathrm{F}$ gene a pair of unlabeled primers (sense 5'-AAC AGG ACA CTG ACC ACT-3', antisense 5'-TGG CAG CAT TCT GGT TGG CT-3') was used to amplify a $196 \mathrm{bp}$ fragment, which contains the region encoding the $\mathrm{F}$ cleavage site (27). For these 2 primers, $25 \mu 1$ reaction mixture for the RRT-PCR contained $19 \mu 1$ master mix (qPCR Core kit for $\mathrm{SYBR}^{\circledR}$ green I, Eurogentec) and $300 \mathrm{nM}$ of each primer according to the manufacturer's recommendation. The GeneAmp software automatically calculates the melting temperature peak $\left(\mathrm{T}_{\mathrm{m}}\right)$ out of the melting curve.

NDV binding and infection of tumor cells. NDV was added to cells in FCS-free medium and incubated for $1 \mathrm{~h}$ in a final volume of $1 \mathrm{ml}$ at $37^{\circ} \mathrm{C}$ in a $\mathrm{CO}_{2}$ incubator. During incubation time the cells were stirred each $15 \mathrm{~min}$. Afterwards the cells were washed twice and used for further experiments.

Flow cytometry. Antibodies were diluted in FACS buffer (PBS containing 5\% FCS and $0.1 \% \mathrm{NaN}_{3}$ ). Cells were washed twice with FACS buffer and then incubated with mouse anti-HN HN.B mAb (IgG2a) (kindly provided by Dr R. Iorio, Department of Molecular Genetics and Microbiology, University of Massachusetts, Medical School Massachusetts, MA) for $30 \mathrm{~min}$. Subsequently the cells were washed and incubated with goat $\mathrm{F}\left(\mathrm{ab}^{\prime}\right) 2$ anti-mouse Ig-RPE (Southern Biotechnology Associates, Inc., Birmingham, USA) for $30 \mathrm{~min}$ on ice in the dark. Analysis was done on a FACScan flow cytometer (Becton-Dickinson, Heidelberg, Germany). FACS data were further analyzed with WinMDI (version 3.9; The Scripps Research Institute, La Jolla, USA) software.

MTS assay. On a 96-well plate, NDV strains were serially diluted and different cell lines were added and a concentration of 50,000 cells per well at a total volume of $100 \mu 1$ in their respective medium. After $48 \mathrm{~h}$ of incubation at $37^{\circ} \mathrm{C}, 20 \mu \mathrm{l}$ MTS (MTS CellTiter $96^{\circledR}$ AQueous, Promega, Mannheim, Germany) to the wells and the plate was incubated for $15-60 \mathrm{~min}$ at $37^{\circ} \mathrm{C}$ in the dark. When the colour switched 
from yellow to brown, reaction was stopped by addition of $20 \mu 110 \%$ SDS and the plates were analyzed in an ELISA reader (Perkin-Elmer Wallac, Freiburg, Germany) at $490 \mathrm{~nm}$. Percent tumor growth inhibition (TGI) for each sample was calculated from the absorbance values $\left(\mathrm{A}_{490}\right)$ according to [1-( $\mathrm{A}_{490}$ sample - $\mathrm{A}_{490}$ background $) /\left(\mathrm{A}_{490}\right.$ negative control $\mathrm{A}_{490}$ background)] x 100 .

Interferon ELISA. PBMC were put into 96-well plates at a concentration of $1 \times 10^{5}$ cells per well and different NDV solutions were added. After 48 -h incubation at $37^{\circ} \mathrm{C}$, the supernatants were removed, freed from cells by centrifugation and ELISA for interferon- $\alpha$ was performed with an interferon- $\alpha$ module set (Bender MedSystems, Vienna, Austria) as recommended by the manufacturer. Reactions were carried out in duplicates.

Tumor neutralisation assay. PBMC were infected with different doses of UV-inactivated NDV strains and incubated in 6-well plates for 3 days containing DMEM supplemented with 5\% FCS. Afterwards the PBMC were put as triplicates in 48-well plates on an MCF7-monolayer of $2.8 \times 10^{4}$ per well at $3.8 \times 10^{5} \mathrm{PBMC}$ per well. After incubation at $37^{\circ} \mathrm{C}$ for 4 days these plates were developed with MTS and TGI was determined as described for the MTS-assay.

Animal experiments. All animals were purchased from Charles River WIMA, Sulzfeld, Germany. For systemic treatment, 6-week-old DBA/2 mice were irradiated with 4.5 Gray 1 day before the inoculation before the intradermal inoculation of $5 \times 10^{6} \mathrm{~Eb}-\mathrm{M} 7$ syngeneic tumor cells. After desensitisation with i.p. injection of $500 \mathrm{HU}$ NDV Ulster on day 1, the animals received 3 i.v. injections of different NDV strains. Each day, body weight and tumor growth was monitored. Tumor volume was calculated according to (greatest diameter) $\mathrm{x}$ (smallest diameter) $)^{2} \mathrm{x} \pi / 6$.

For locoregional therapy we used a subcutaneous splitspleen reservoir model for multiple portal venous injections (28). On day 1, 8-week-old BALB/c mice underwent surgery under anesthesia with i.p. injection of $150 \mu 1$ solution containing $600 \mu \mathrm{g}$ xylazine (Rompun ${ }^{\circledR}$, Bayer, Leverkusen, Germany) and $1250 \mu \mathrm{g}$ ketamine $\left(\right.$ Ketanest $^{\circledR} \mathrm{S}$, Pfizer, Karlsruhe, Germany) in PBS. The mouse was placed on its right flank, the left flank was shaven and a small cutanous incision was made. After preparation of a small subcutaneous pocket and incision of the peritoneum, the spleen was carefully mobilized on its vascular pedicle and ligated between the two splenic vascular bundles. Cells $\left(5 \times 10^{5}\right)$ CT26-luc were injected into the upper pole. After $10 \mathrm{~min}$ the vascular bundle of the upper pole was ligated and the hemi-spleen was removed. The lower pole was transposed subcutaneously while preserving its vascular bundle, and hold in place with a suture closing the peritoneum, followed by a suture closing the skin. All ligatures and sutures were performed with Prolene 5-0 (Ethicon, Norderstedt, Germany). Every 3 days beginning with day 1 the mice were weighed and tumor load was determined by in vivo bioluminescence imaging on an IVIS ${ }^{\circledR}$ Imaging System 100 (Xenogen Corporation, Hopkinton, USA). Therefore, mice were anesthetized with $400 \mu \mathrm{g}$ xylazine and $1000 \mu \mathrm{g}$ ketamine, received an i.p. injection of $4.5 \mathrm{mg}$ luciferine and were measured with high resolution binning. A ROI was set on the upper abdomen covering the liver.

Serum levels of GOT and GPT liver enzymes and interferon after regional NDV application. B ALB/c mice were anesthetized with $600 \mu \mathrm{g}$ xylazine and $1250 \mu \mathrm{g}$ ketamine and received a single intrasplenic injection of $1,000 \mathrm{HU}$ NDV $M T H-68 / H$ or PBS. Control mice received an i.v. injection of the same virus dose or PBS. After $12 \mathrm{~h}$ mice were sacrificed by heart puncture under anaesthesia. Serum levels of glutamate oxalacetate transaminase (GOT) and glutamate pyruvate transaminase (GPT) were determined by LaboKlin, Bad Kissingen, Germany. Interferon bioactivity was kindly determined by Dr R. Zawatzky (German Cancer Research Center, Heidelberg, Germany) with a VSV infection inhibition assay.

\section{Results}

Virological characterization of different NDV strains. In order to determine the number of infective particles, we performed a serial dilution endpoint assay on a Vero cell monolayer. The cells were infected with NDV of the strains MTH-68/H, Italian, NDFLtag-EGFP and Ulster for 6 days and then stained with crystal violet (Fig. 1A). The 2 oncolytic strains $M T H-68 / H$ and Italian had similar lytic capacity whereas NDFLtag-EGFP lysed the cells only at a much higher concentration. No lysis was seen with the non-virulent strain Ulster. Table I lists the tissue culture infectivity dose of $50 \%$ $\left(\mathrm{TCID}_{50}\right)$ for $1,000 \mathrm{HU}$ as determined by the formula of Reed and Münch (25).

To look at the F protein cleavage site of $M T H-68 / H$, of which no sequence is published yet, we analysed the F cDNAs by quantitative real-time PCR (RT-PCR) and determined the melting curves (Fig. 1B). The peak temperature of the melting curve $\left(\mathrm{T}_{\mathrm{m}}\right)$ was about $1{ }^{\circ} \mathrm{C}$ lower for the oncolytic strains $M T H-68 / H$ and Italian than for the non-oncolytic strains Ulster and NDFLtag-EGFP (Table I). Additionally we quantified the $\mathrm{M}$ genes by RT-PCR. Here all viruses showed very similar copy numbers ranging from 450,000 to 800,000 per HU (Table I).

In vitro anti-tumoral activity. To compare the anti-tumoral activity of the NDV strains in vitro, we added serial dilutions of NDV MTH-68/H, Italian and Ulster to monolayers of human HeLa cervix and MCF7 breast carcinoma cells, to murine Eb-M7 and ESb-MP lymphoma cell lines and to the luciferase gene transfected murine colon carcinoma CT26-luc. For comparison we used avian QM5 cells. After $48 \mathrm{~h}$, MTS was added and tumor growth inhibition (TGI) determined as a percentage of living cells after addition of virus compared to living cells without virus (Fig. 2A). The oncolytic behaviour of $M T H-68 / H$ and Italian was very similar. The $\mathrm{TGI}_{50}$ was at the dilutions $1: 1,000$ to $1: 10,000$ for HeLa, 1:1 for MCF7 and 1:100 to 1:1,000 for Eb-M7. No $\mathrm{TGI}_{50}$ could be determined for the murine tumor lines ESbMP and CT26-luc. NDV Ulster showed much lower TGI values. For Eb-M7 the $\mathrm{TGI}_{50}$ of Ulster was at 2-3 logs lower dilutions than for the two oncolytic strains. 

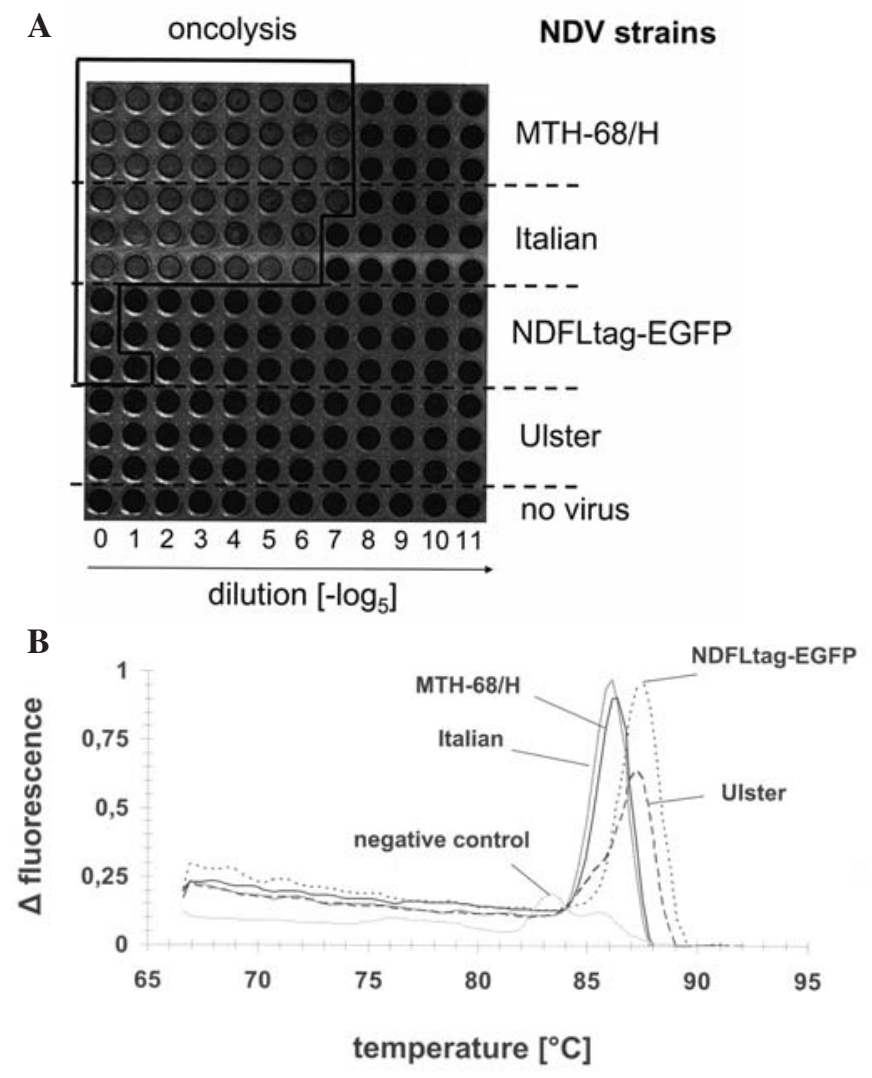

Figure 1. Virological characterization of the NDV strains used. (A) Virus dilution endpoint assay with crystal violet staining. NDV strains $(M T H-68 / H$, Italian, NDFLtag-EGFP and Ulster) were added onto a confluent monolayer of Vero cells starting with a dose of $50 \mathrm{HU}$ per well. After 6 days the wells were stained with crystal violet. The wells where the cell monolayer was damaged through viral oncolysis are highlighted. (B) Melting curves of a 196 bp fragment containing the F cleavage site amplified by RRT-PCR.

Table I. Summary of virological properties for the different NDV strains.

\begin{tabular}{lccc}
\hline & TCID $_{50}{ }^{\mathrm{a}}$ & $\mathrm{T}_{\mathrm{m}}\left({ }^{\circ} \mathrm{C}\right)^{\mathrm{b}}$ & M copy no. \\
\hline MTH-68/H & $10^{-7.8}$ & 86.1 & 633,291 \\
Italian & $10^{-7.3}$ & 86.2 & 478,186 \\
NDFLtag-EGFP & $10^{-3.1}$ & 87.4 & 554,383 \\
Ulster & $\mathrm{Neg}$ & 87.2 & 787,893 \\
\hline
\end{tabular}

$\mathrm{TCID}_{50}$ for lytic strains Italian, MTH-68/H, NFLtag-EGFP and for the non-lytic strain Ulster was calculated with the Reed and Münchformula after dilution endpoint assay of Fig. 1A. The melting temperatures $\left(\mathrm{T}_{\mathrm{m}}\right)$ were determined after melting curve analysis of Fig. 1B. Absolute quantification of the $\mathrm{M}$ gene of the viral genome was performed via RRT-PCR as described in Materials and methods. ${ }^{a}$ For $1,000 \mathrm{HU} / \mathrm{ml}$ (dilution endpoint assay); ${ }^{\mathrm{b}}$ of F cDNA melting curve (RRT-PCR); ' for 1 HU (RRT-PCR).

To compare the replication of $M T H-68 / H$ and Italian, QM5 and HeLa cells were infected with both viruses at different doses (Fig. 2B). After $1 \mathrm{~h}$ we tested virus adsorption by staining the cells with anti-HN and performing FACS analysis. $M T H-68 / H$ and Italian showed nearly identical $\mathrm{HN}$ profiles. After $24 \mathrm{~h}$ of incubation, we tested for increase of cell surface $\mathrm{HN}$ expression density as a sign of virus replication as was done previously (24). For QM5 cells, strain Italian showed the highest mean fluorescence at the highest infection dose. For HeLa cells, strain $M T H-68 / H$ had similar $\mathrm{HN}$-expression profiles for all three infection doses, while strain Italian could only reach this expression level at the highest infection dose.

Immune modulatory properties. In order to evaluate the influence of the different NDV strains on the immune system, we tested the interferon- $\alpha$ response of human PBMC upon stimulation with live or UV-inactivated virus. Fig. 3A shows the interferon- $\alpha$ concentration in the supernatants as determined by ELISA. MTH- $68 / H$ had the highest interferon- $\alpha$ inducing capacity with a maximum of $722 \mathrm{pg} / \mathrm{ml}$ at an infection dose of $10 \mathrm{HU}$ per $10^{7}$ cells. With UVinactivated virus, the interferon- $\alpha$ response of PBMC was greatly reduced.

To determine if the interferon response might correlate with an anti-tumor effect, we performed tumor neutralisation (TNA) assays. For this purpose NDV-infected irradiated MCF7 vaccine cells were coincubated with PBMC on a MCF7 monolayer. After 6 days, viable cell staining with MTS was performed and tumor growth inhibition (TGI) determined. When using live virus of strains Italian and $M T H-68 / H$ for vaccine production a high anti-tumor effect with TGI up to $90 \%$ was observed irrespective of the presence of PBMC (data not shown). To exclude direct oncolytic effects of the virus in the TNA, we performed further experiments with UV-inactivated virus. After 4 days of co-incubation of PBMC with virus (UV) on top of MCF7 monolayers, the \% TGI was determined. $M T H-68 / H$ (UV) treated PBMC (1,000 and $100 \mathrm{HU}$ per $10^{7}$ cells) showed a significant elevation of the \% TGI compared to PBMC without virus. Italian (UV) and Ulster (UV) did not induce a significant TGI effect in vitro.

Anti-tumor effects after systemic i.v. virus application. Subsequently we evaluated the anti-tumor effects of systemically applied oncolytic NDV strains. Irradiated 6-week-old DBA/ 2 mice were inoculated with $5 \times 10^{6}$ syngeneic Eb-M7 tumor cells intradermally at day 0 . After desensitisation by intraperitoneal injection of $500 \mathrm{HU}$ NDV Ulster (day 1), treatment was performed on day 2-4 with three i.v. injections of $1,000 \mathrm{HU} M T H-68 / \mathrm{H}$ or Italian. Body weight and tumor volume were monitored each day. On days 4 to 12 there were several significant body weight drops in the $M T H-68 / H$ group and only one drop in the Italian group (Fig. 4A). During this period also a slight delay of tumor growth could be observed in the $M T H-68 / H$ group, but this difference was not significant (Fig. 4B).

Anti-tumor effects after locoregional virus application. In order to evaluate anti-tumor effects on liver metastases by locoregional application, we used a subcutaneous splitspleen reservoir model $(28,29)$ and combined it with in vivo bioluminescence imaging (30). The experiments were performed in $\mathrm{BALB} / \mathrm{c}$ mice with the syngeneic tumor line 
A

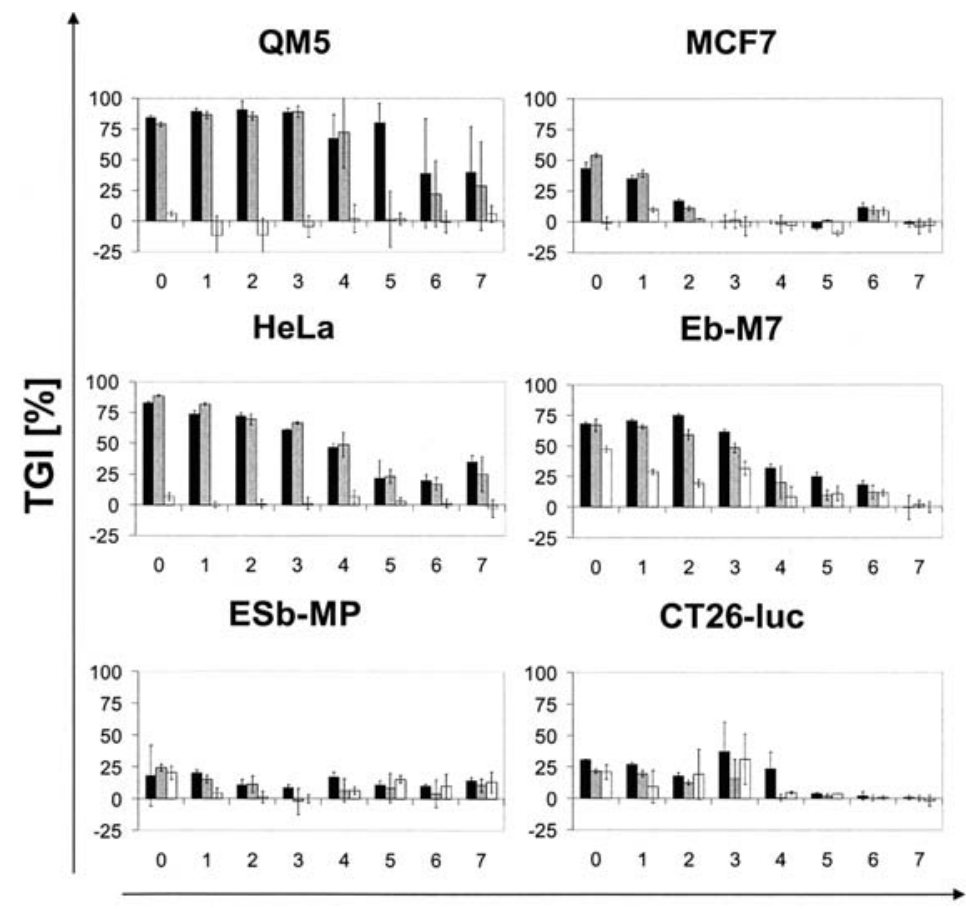

\section{dilution $\left[-\log _{10}\right]$}

$\mathbf{B}$

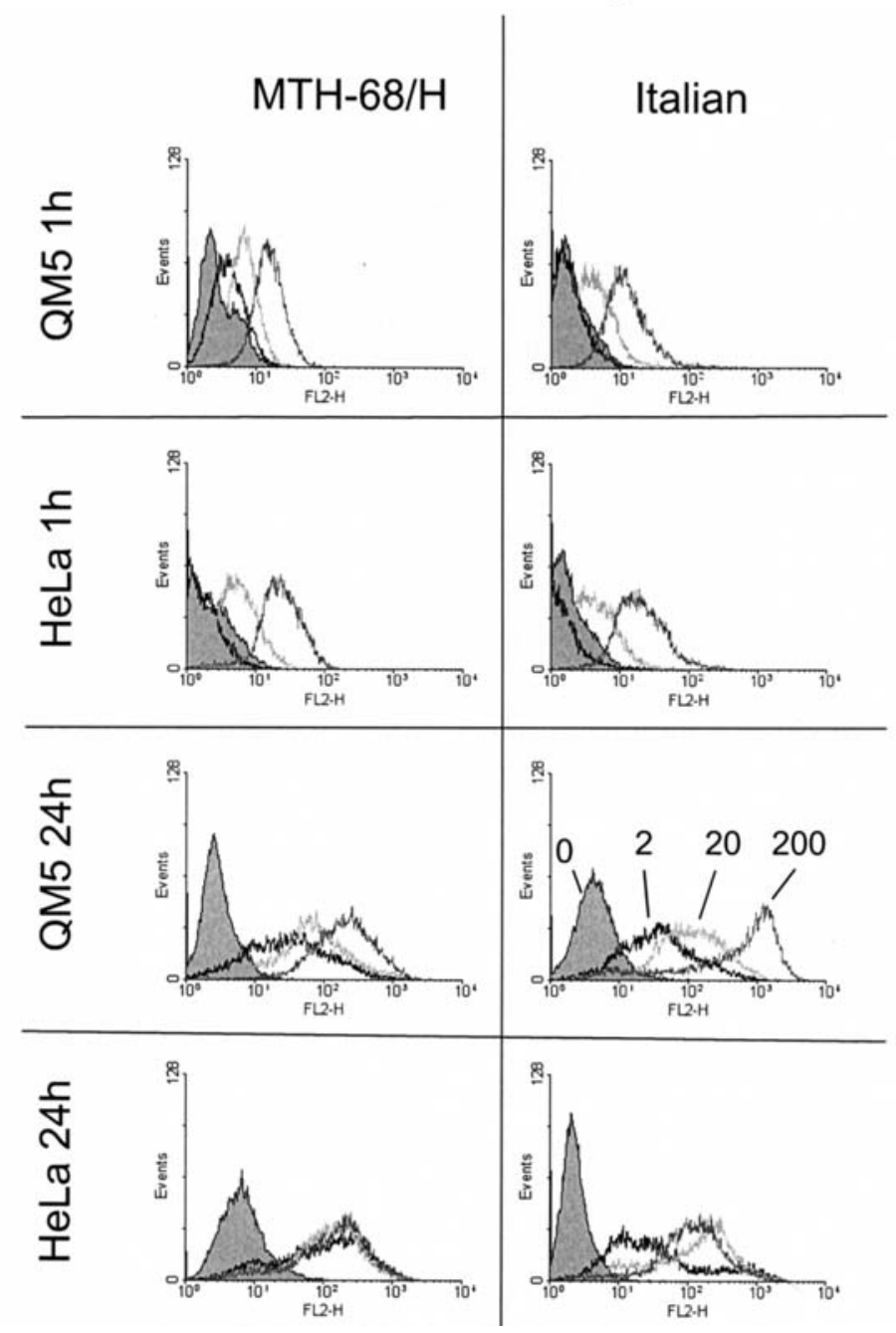

Figure 2. In vitro anti-tumor activity of different NDV strains. (A) The cell lines indicated (50,000 cells per well) were transferred into 96-well plates and the serially diluted viruses were added in triplicates starting at a dose of $5 \mathrm{HU}$ per well. After $48 \mathrm{~h}$, tumor growth inhibition was determined by development with MTS. For calculation of \% tumor growth inhibition (TGI), the negative control was set to zero. (B) QMS and HeLa cells were infected with the indicated NDV strains. After 1 and $24 \mathrm{~h} \mathrm{FACS}$-analysis for HN was performed, in order to test for cells surface absorbed (1 h) and for virus replication (24 h). (B) QM5 and HeLa cells were infected with the indicated NDV strains. After 1 and $24 \mathrm{~h} \mathrm{FACS}$-analysis for HN was performed, in order to test for cell surface adsorbed virus ( $1 \mathrm{~h}$ ) and for virus replication (24 h). Black bars, $M T H-68 / H$; grey bars, Italian; white bars, Ulster. 
A

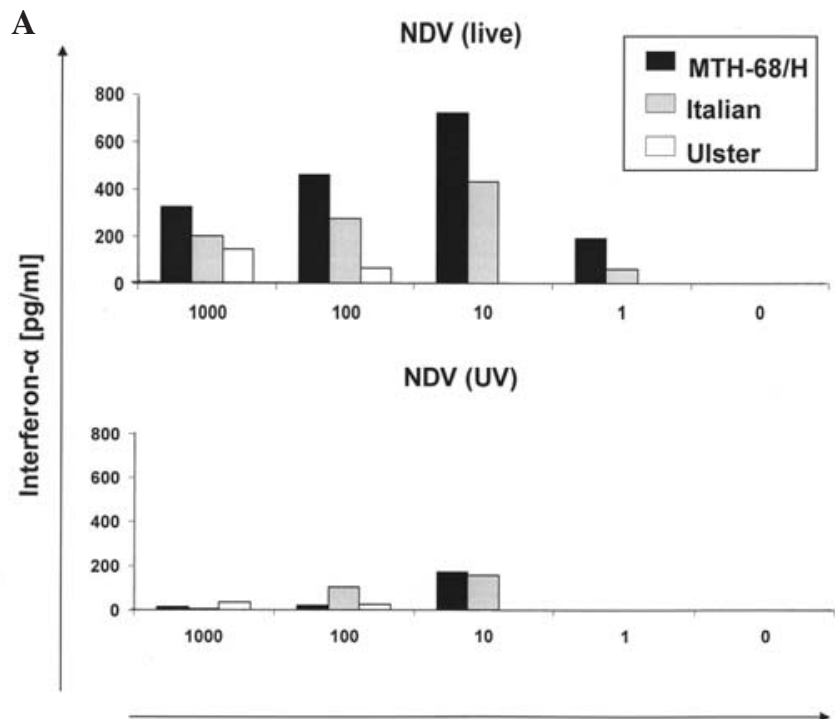

NDV $\left[\mathrm{HU} / 10^{7} \mathrm{PBMC}\right]$

B

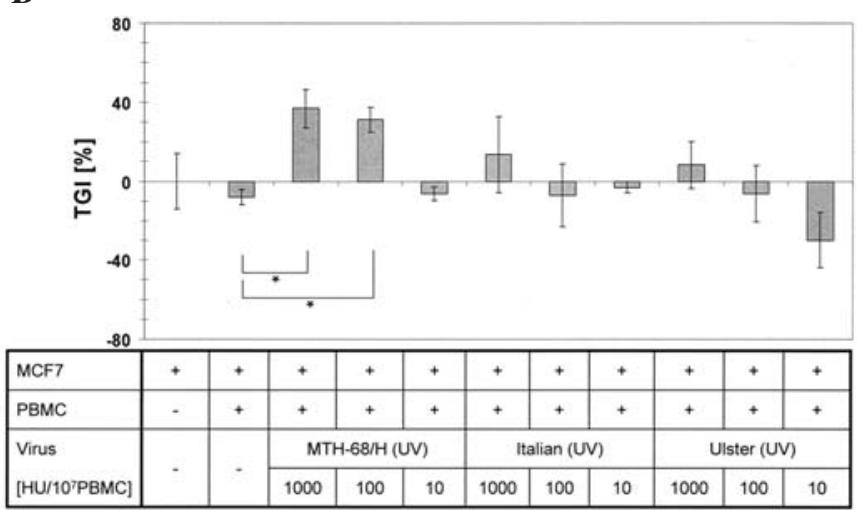

Figure 3. Immune modulatory properties of different NDV strains. (A) Human PBMC were tested with NDV (live) or UV-inactivated NDV [(NDV (UV)] and placed in 96 -well plates at $1 \times 10^{6}$ cells per well. After $24 \mathrm{~h}$, the interferon- $\alpha$ concentration in the supernatants was measured by ELISA. When the experiment was repeated with PBMCs from another donor, the same trend was seen although the absolute interferon concentrations were different. (B) Human PBMC were treated with NDV (UV) at different doses and placed in 6-well plates at $5 \times 10^{6}$ cells per well. After 3 days, the PBMC were transferred in triplicates onto MCF7 monolayers at a concentration of $3.8 \times 10^{5}$ cells per well. Tumor growth inhibition was determined after 4 additional days by development with MTS. ${ }^{*} \mathrm{p}<0.05$.

CT26-luc. Fig. 5A illustrates the treatment protocol. First, tumor cells are inoculated through a separated part of a spleen through which they can enter the liver. Seven to nine days later $M T H-68 / H$ virus is applied through s.c. transposed hemi-spleen. From day 9 to day 15 there was a reduction in tumor growth as shown by representative images of the treated mice (Fig. 5B). While this delay in tumor growth was significant (Fig. 6A), there were no significant difference in body weights (Fig. 6B). The $M T H-68 / H$ treated mice also showed a significantly longer median survival than the control (23.5 vs. 18.0 days) (Fig. 6C).

Resistance of CT26-luc cells to NDV MTH-68/H infection. When the CT26-luc cells were examined for NDV susceptibility no $\mathrm{TGI}_{50}$ effect was achieved in the MTS-assay (Fig. 2A). The FACS analysis for HN expression $1 \mathrm{~h}$ after
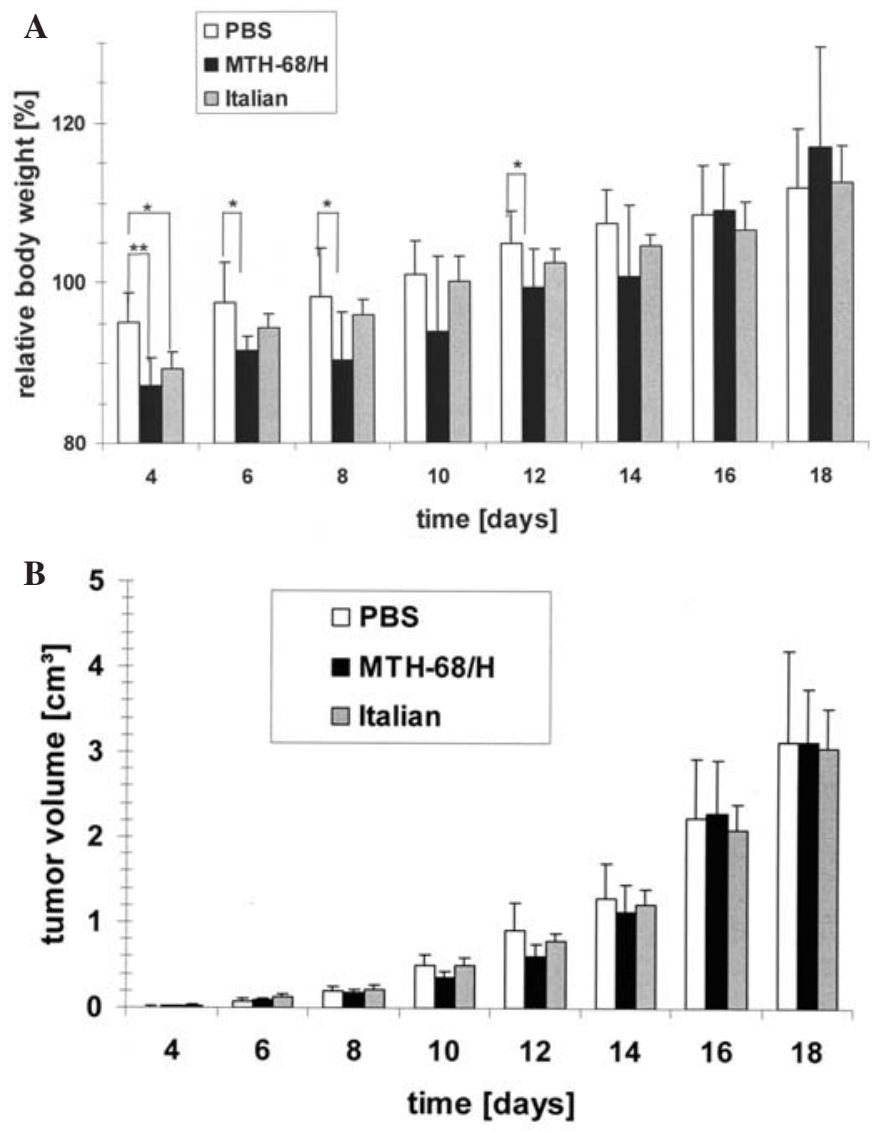

Figure 4. Systemic treatment of intradermal tumors with NDV. DBA/2 mice, pre-irradiated at d-1 with $5 \mathrm{~Gy}$, were inoculated with $5 \times 10^{6} \mathrm{~Eb}-\mathrm{M} 7$ tumor cells intradermally at day 0 . At day 1 the treatment groups (for each of them, $n=9$ ) were desensitized by intraperitoneal injection of $500 \mathrm{HU}$ NDV Ulster. At days 2-4 they received 1,000 HU of NDV Italian or $M T H-68 / H$ via tail vein injection. The control mice $(n=9)$ received PBS instead. Body weights with bars indicating standard deviation (A) and tumor volumes with bars indicating standard error of the mean (SEM) (B) were determined. ${ }^{*} \mathrm{p}<0.05$.

NDV infection revealed a dose-dependent binding behaviour similar to the previously depicted QM5 and HeLa cell lines (Fig. 7A). HN-staining after $24 \mathrm{~h}$, a test for NDV-replication, showed almost no staining for $M T H-68 / H$ and Ulster and only very low mean fluorescence for Italian, thus indicating resistance of this line to NDV infection.

Serum levels of liver transaminases and interferon after MTH-68/H administration. In order to evaluate a possible mechanism of the in vivo effects of NDV $M T H-68 / H$, we administered $1,000 \mathrm{HU}$ of $M T H-68 / H$ to BALB/c mice intravenously or by intrasplenic injection. After $24 \mathrm{~h}$ the mice were anaesthesized and sacrificed by heart puncture. The activity of the liver enzymes glutamate-oxalacetatetransaminase (GOT) and glutamate-pyruvate-transaminase (GPT) as well as interferon bioactivity was determined in the serum (Fig. 7B). Mice treated with intrasplenic injection of $M T H-68 / H$ showed a significant elevation of GPT serum activity in comparison to all other groups. The GOT elevation was only significant in comparison to the group treated with PBS intravenously. Interferon bioactivity was significantly elevated in both groups treated with $M T H-68 / H$ with higher levels in the intravenously treated mice. 
A

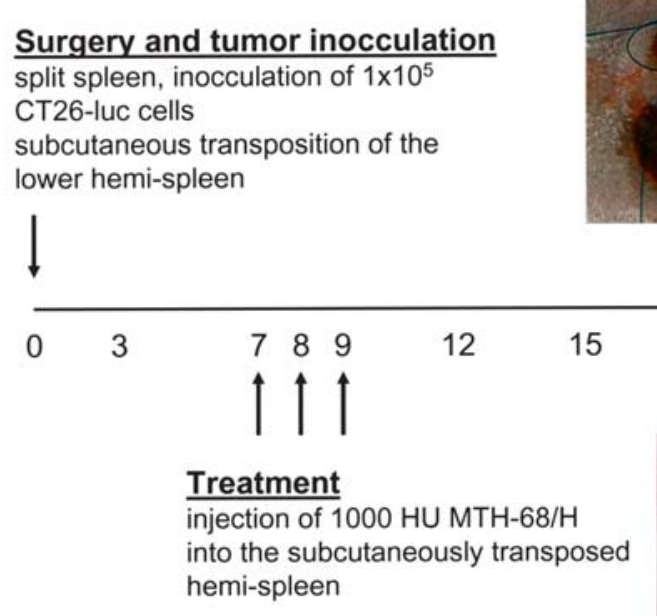

B

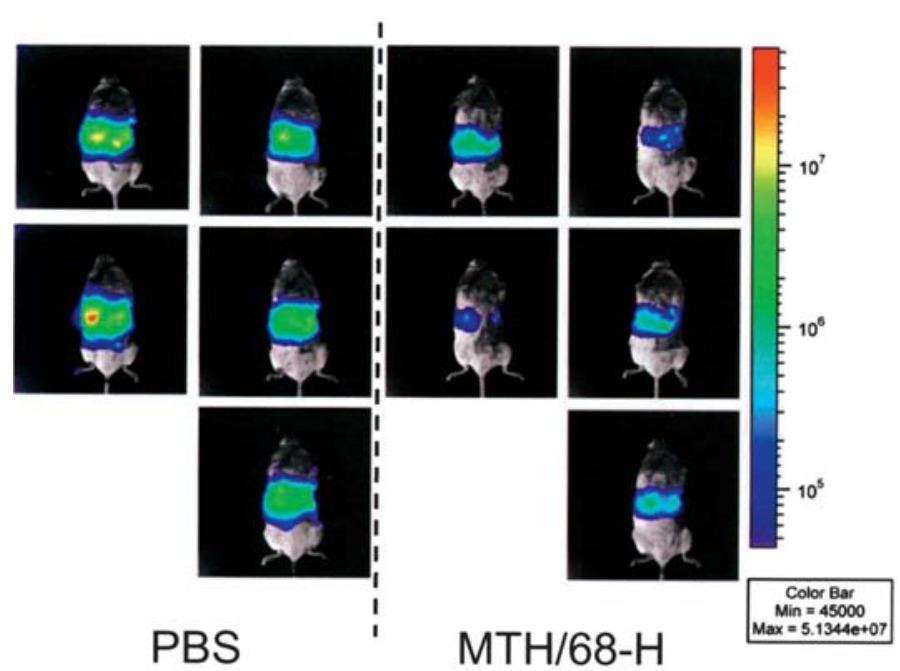

B day 9

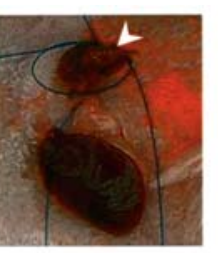

18 time [days]

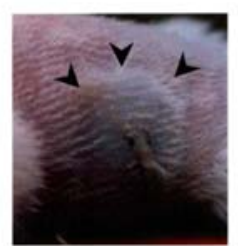

Figure 5. Locoregional treatment of liver metastases: tumor growth reduction. (A) Scheme of the treatment protocol. On day 0, BALB/c mice underwent surgery: after anesthesia the spleen was mobilised on its vascular pedicle and ligated. The two hemi-spleens are shown in the upper photograph. $1 \mathrm{x} 10^{5} \mathrm{CT} 26-$ luc cells were injected into the upper hemi-spleen (white arrowhead). After $10 \mathrm{~min}$, the upper hemi-spleen was removed and the lower hemi-spleen was transposed subcutaneously. On days 7-9 the mice were treated by 3 injections of 1,000 HU MTH-68/H into the subcutaneously transposed hemi-spleen (black arrowheads in lower photograph). (B) In vivo bioluminescence imaging was performed at the days 9-15 for the group of mice treated with PBS and for the other one that corresponds to mice treated with $M T H-68 / H$.

\section{Discussion}

RNA viruses have received considerable attention recently as virotherapy agents $(31,32)$ and as oncolytic viral therapeutics $(32,34,35)$. In this study we have investigated anti-tumor effects of an oncolytic RNA virus (NDV) after short-term systemic or locoregional application to tumor-bearing mice. One tumor model, the mouse lymphoma Eb-M7 (13), consists of cells which are sensitive to NDV replication and toxicity while the other tumor model, the luciferase transfected murine colon-carcinoma CT26-luc (36), was resistant to NDV replication and toxicity. The virus was given either into the tail vein for systemic treatment of Eb-M7 tumors or it was given into a subcutaneously transposed spleen segment for locoregional treatment of liver metastases from CT26-luc tumor cells. For locoregional treatment of liver malignancies, injection of viruses into the hepatic artery has been described for rats (29). For mice, however, because of the size difference, only the intraportal route is feasible. We used the subcutaneous split-spleen reservoir model for multiple portal venous injections (28) for three purposes: i) for production of diffuse artificial liver metastases after locoregional tumor cell application into a separated spleen segment; ii) for independent intrasplenic application of virus so that there can be no contact between virus and tumor cells before they enter the liver; and iii) for multiple intrasplenic injections of virus without the need of performing further laparotomies. In order to assess tumor growth continuously, we combined this model with in vivo bioluminescence imaging which has been shown to correlate well with hepatic tumor burden in mice (30). The experiments revealed that there was no significant antitumor effect after i.v. treatment of virus-sensitive Eb-M7 tumors while in the virus resistant CT26-luc tumor model locoregional treatment resulted in a significant retardation of tumor growth and prolongation of survival. The latter result suggests that the oncolytic NDV strain can exert a loco- 
A

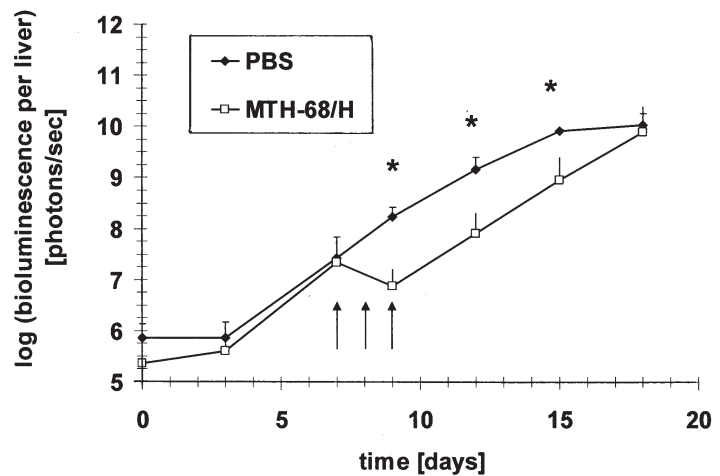

B

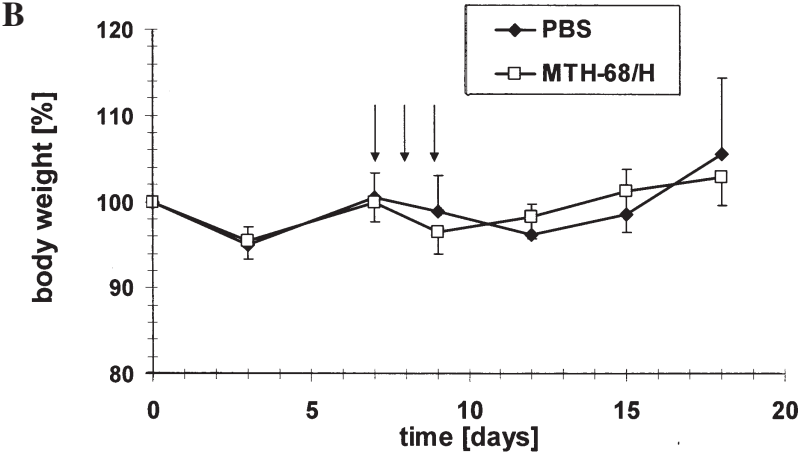

C

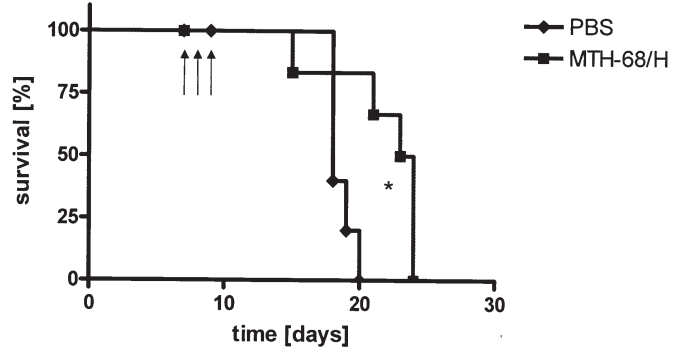

Figure 6. Locoregional treatment of liver metastases: delay in tumor growth and prolongation of median survival without significant changes of body weigth. (A) Mean bioluminescence per liver. In vivo bioluminescence imaging were performed at the days indicated for the group of mice treated with PBS as negative control $(n=5)$ and for the other one that corresponds to mice treated with $M T H 68 / H(\mathrm{n}=6)$. (B) Mean body weights: they were determinated at the days indicated for the group of mice treated with PBS as negative control $(\mathrm{n}=5)$ and for the other one that corresponds to mice treated with MTH-68/H (n=6). (C) Survival. Treatment days are marked with arrows. ${ }^{*} \mathrm{p}<0.05$.

regional host mediated anti-tumor effect. Why systemic treatment of the virus sensitive tumor did not give similar or even stronger anti-tumor effects remains unclear. It may have to do with the difference between tail vein and splenic application. That the route of virus application is important is corroborated by the analysis of body weight loss as a sign of overall stress of the animals. While tail vein application caused a significant body weight drop, this was not the case after intrasplenic application.

Our conclusion that the anti-tumor effect seen in the CT26-luc tumor model after locoregional virus application is mostly host mediated is supported by in vitro data: i) The oncolytic virus strain had a strong capacity to induce interferon- $\alpha$ in human PBMC and ii) oncolytic virus that was inactivated by UV-irradiation was able to activate PBMC to exert bystander anti-tumor activity in a tumor neutralization assay in vitro. These findings suggest that this virus strain is not only oncolytic but also strongly immuno-stimulatory.
The attenuated, purified $M T H-68 / H$ strain was reported to have beneficial effects in patients with advanced cancer $(19,37)$ and since this virus exerted direct cytotoxicity in vitro against several tumor cell lines (20) it was concluded that direct cytotoxicity and oncolysis is the key factor of anti-tumor activity of this virus strain (20). This assumption, however, is not corroborated by data from in vivo tumor models or from clinical studies. The results obtained in this study, where a virus resistant tumor cell line could be successfully treated argues against oncolysis as the main mechanism of in vivo activity of this virus.

We analyzed in the serum of virus treated mice the liver enzymes GPT and GOT. Both enzymes were elevated after intrasplenic virus application and the elevation of GPT was significantly higher than that after intravenous virus application. These data demonstrate a locoregional effect of the virus on the target organ. We also analyzed serum levels of murine interferon- $\alpha$. While there was a slight increase after intrasplenic inoculation, intravenous application resulted in a significantly stronger serum interferon titer. These results demonstrate that $M T H-68 / H$ induces interferon- $\alpha$ not only in human PBMC but also in mice. Virulent strains of NDV can be pathogenic in chicken. They can grow in interferon responsive chicken cells because this avian virus encodes an interferon antagonist, the viral (V) protein (38). This viral protein can disrupt interferon-signalling in chicken cells, but not in mammalian cells, by binding to one of the signal transducer and activation of transcription (STAT) proteins (39). We described before that in human cells the NDV induced interferon- $\alpha$ causes upregulation of MHC molecules on tumor cells (40). This can lead to potentiation of cytolytic T cell activity (41). Furthermore, we showed that NDV can activate in monocytes NF-кB (42), nitric oxide (NO) production (42) and cell surface expression of TRAIL (43). NDV activated mouse (4) and human (43) macrophages/ monocytes were able to kill tumor cells. Upon adoptive transfer into tumor-bearing mice they transferred anti-tumor activity (4). We also demonstrated before in mouse (45) and human cells (46) that NDV derived HN molecules on antigen-presenting cells confer $\mathrm{T}$ cell costimulatory activity and augment their anti-tumor cytotoxic activity. Oncolytic NDV strains produce oncolysates upon tumor cell infection. We have shown that NDV derived oncolysates are processed by dendritic cells which then potently stimulate autologous $\mathrm{T}$ cells from cancer patients (47). Together, these findings provide examples of host mechanisms through which also oncolytic NDV could exert anti-tumor activity.

In contrast to these host mediated immune mechanisms, direct oncolytic effects after systemic virus application would require successful targeting of the virus to the tumor. When we examined this in previous studies, we found that some viruses can indeed target the tumors. This, however, is by no means a highly efficient system. A large amount of virus is found in non-target tissues (13). Anti-tumor effects of NDV are usually stronger when the virus is applied locally than when given systemically $(48,49)$.

A Hungarian group studied strain $M T H-68 / H$ as a treatment for patients with various cancers. They reported on a case series of 4 patients (37) and even a phase II trial (50). It was used for instance for treatment of a 14-year-old boy 
$\mathbf{A}$
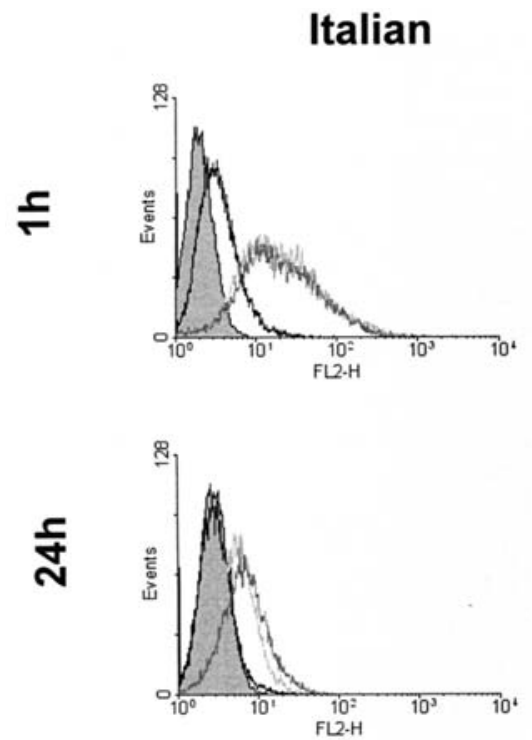

B

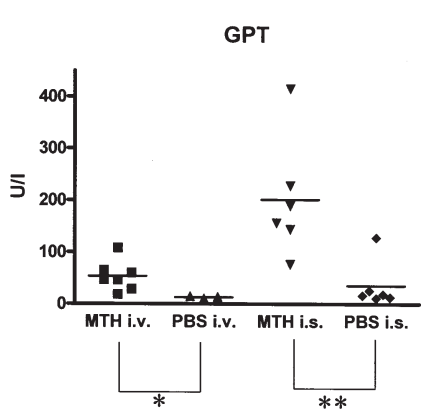

MTH-68/H
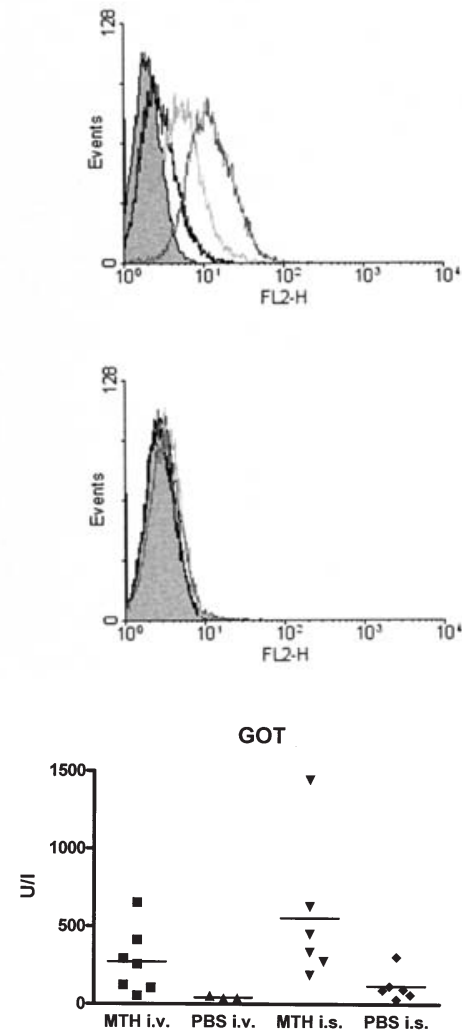

Ulster
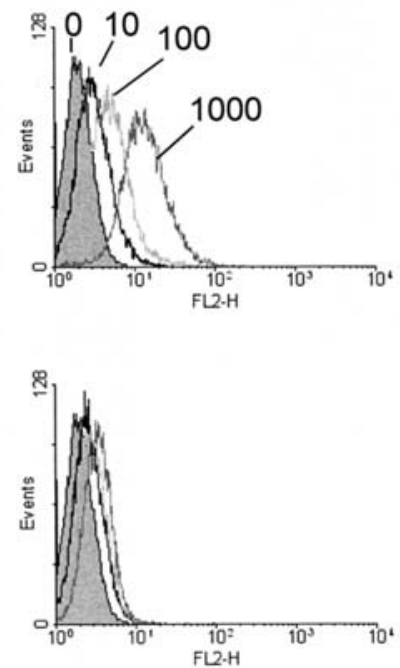

Interferon- $\alpha$

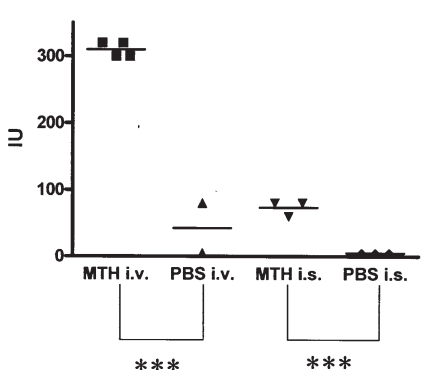

Figure 7. Virus resistance of CT26-luc cells and virus induced host effects. (A) CT26-luc cells were infected with NDV at the given doses. After $1 \mathrm{~h}$ and after $24 \mathrm{~h} \mathrm{HN}$ expression was determining by FACS. (B) BALB/c mice underwent intrasplenic or tail vein injection of $1,000 \mathrm{HU} M T H-68 / H$ or PBS. After $24-\mathrm{h}$ serum activity of GOT and GPT (in units per liter) as well as interferon bioactivity (in international units) were measured. ${ }^{*} \mathrm{p}<0.05 .{ }^{* *} \mathrm{p}<0.01 .{ }^{* * *} \mathrm{p}<0.001$.

diagnosed with glioblastoma (GBM) that was debulked, irradiated and treated with chemotherapy but recurred over a year later and caused a great decline in functional and neurological status (51). This patient's recurrence has been treated intravenously with NDV daily since April 1996. Between November 1996 and September 1998 the recurrence showed progressive shrinking. At the last report the patient was tapered off dexamethasone and chemotherapy and received no medication other than NDV treatment. From a phase I/II study of anti-tumor vaccination of $23 \mathrm{GBM}$ patients with the ATV-NDV tumor vaccine we reported on improvements of anti-tumor immunity and overall survival (16). These findings offer much hope for the use of NDV in the treatment of primary brain tumors. Of course, much more research has to be performed regarding the mode of application and mechanism of in vivo action of this virus.

Another lytic NDV strain, named PV701, which is mesogenic, has been applied systemically in 3 phase I clinical studies with late stage cancer patients (see ref. 52 for the results about the last optimizations). In a dose-escalation study, PV701 was well tolerated in doses of at least $3 \times 10^{9}$ infectious units by the i.v. route and at least $4 \times 10^{12}$ infectious units by the intratumoral route. Efficient distribution of an oncolytic virus to the tumor site seems to be critical (53).

We characterized in this study an oncolytic NDV strain which is capable to selectively destroy tumor cells and which kills them in a way that differs from that of most cytotoxic chemical drugs. While such a replication competent virological agent may become an important adjunct to standard cancer treatment, its optimal mode of application and its in vivo mechanisms of anti-tumor activity need to be better understood.

The role of host immune responses in the efficacy or toxicity of oncolytic virus therapy is poorly defined. To optimize oncolytic effects, it may be of advantage to transiently suppress innate immune responses, for instance by cyclophosphamide (54), but care should be taken that oncolysis stimulates adaptative immunity, setting up an anti-cancer vaccination effect.

We describe here that $M T H-68 / H$ upon locoregional application can exert anti-tumor activity even against an oncolysis resitant tumor line. Our interpretation that this virus can exert not only direct but also host immunity mediated effects is supported by the observation that the effects observed in patients $(16,51)$ often develop only slowly and are sometimes long-lasting. This is typical for immune mediated effects as seen in immunotherapy trials $(4,5,15)$.

\section{Acknowledgments}

The results presented in this manuscript are part of the MD thesis performed in our laboratory by Leonidas Apostolidis. 
We acknowledge Dr Gerhard Noss who provided us with the $M T H-68 / H$ strain, Dr Olaf van Tellingen who gave us the CT26 cell line permanently transfected with a plasmid encoding the luciferase gene, Dr Ben Peeters for the recombinant NDV strain NDFLtag-EGFP and for his kind support, Holger Wilden for his help in the realisation of the RRT-PCR and Dr Rainer Zawatzky for the determination of interferon activity in some samples. We thank Annette Arnold and Andreas Griesbach for their excellent technical assistance.

\section{References}

1. Shah AC, Benos D, Gillespie GY and Markert JM: Oncolytic viruses: clinical applications as vectors for the treatment of malignant gliomas. J Neurooncol 65: 203-226, 2003.

2. Parato KA, Senger D, Forsyth PAJ and Bell JC: Recent progress in the battle between oncolytic viruses and tumours. Nat Rev 5: 965-976, 2005.

3. Cassel WA and Garret RE: Newcastle disease virus as an antineoplastic agent. Cancer 18: 863-868, 1965.

4. Schirrmacher V, Ahlert T, Probstle T, et al: Immunization with virus-modified tumor cells. Semin Oncol 25: 677-696, 1998.

5. Heicappell R, Schirrmacher V, von Hoegen P, Ahlert T and Appelhans B: Prevention of metastatic spread by postoperative immunotherapy with virally modified autologous tumor cells. I. Parameters for optimal therapeutic effects. Int J Cancer 37 : $569-577,1986$.

6. Alexander DJ and Allan WH: Newcastle disease virus pathotypes. Avian Path 3: 269-278, 1974.

7. Peeters BP, De Leeuw OS, Koch G and Gielkens AL: Rescue of Newcastle disease virus from cloned cDNA: evidence that cleavability of the fusion protein is a major determinant for virulence. J Virol 73: 5001-5009, 1999.

8. Cassel WA, Murras DR, Torbin AH, Olkowski ZL and Moore ME: Viral oncolysate in the management of malignant melanoma. I. Preparation of the oncolysate and measurement of immunologic responses. Cancer 40: 672-679, 1977.

9. Lorence RM, Katubig BB, Reichard KW, Reyes HM, et al: Complete regression of human fibrosarcoma xenografts after local Newcastle disease virus therapy. Cancer Res 54: 6017-6021, 1994.

10. Lorence RM, Reichard KW, Katubig BB, et al: Complete regression of human neuroblastoma xenografts in athymic mice after local Newcastle disease virus therapy. J Natl Cancer Inst 861: 1228-1233, 1994.

11. Reichard KW, Lorence RM, Ascino CJ, et al: Newcastle disease virus selectively kills human tumor cells. J Surg Res 52: 448-453, 1992.

12. Fiola C, Peeters B, Fournier P, Arnold A, Bucur M and Schirrmacher V: Tumor-selective replication of Newcastle disease virus: association with defects of tumor cells defence. Int J Cancer 119: 328-338, 2006.

13. Bian H, Wilden H, Fournier P, Peeters B and Schirrmacher V: In vivo efficacy of systemic tumor targeting of a viral RNA vector with oncolytic properties using a bispecific adapter protein. Int J Oncol 29: 1359-1369, 2006

14. Schirrmacher V, Haas C, Bonifer R, Ahlert T, Gerhards R and Ertel C: Human tumor cell modification by virus infection: an efficient and safe way to produce cancer vaccine with pleiotropic immune stimulatory properties when using Newcastle disease virus. Gene Therap 6: 63-73, 1999.

15. Schirrmacher V: Clinical trials of antitumor vaccination with an autologous tumor cell vaccine modified by virus infection: improvement of patient survival based on improved anti-tumor immune memory. Cancer Immunol Immunother 54/6: 587-598, 2005.

16. Steiner HH, Bonsanto MM, Beckhove P, et al: Anti-tumor vaccination of patients with glioblastoma multiforme: a pilot study to assess: feasibility, safety and clinical benefit. J Clin Oncol 22: 4272-4281, 2004.

17. Karcher J, Dyckhoff G, Beckhove P, et al: Anti-tumor vaccination with HNSCC with autologous virus-modified tumor cells. Cancer Res 64: 8057-8061, 2004.

18. Czegledi A, Wehmann E and Lomniczi B: On the origins and relationships of Newcastle disease virus vaccine strains Hertfordshire and Mukteswar, and virulent strain Herts'33. Avian Pathol 32: 271-276, 2003.
19. Csatary LK, Gosztonyi G, Szeberenyi J, et al: MTH-68/H oncolytic viral treatment in human high-grade gliomas. J Neurooncol 67: 83-93, 2004.

20. Zsolt F, Csatary CM, Szeberényi J and Csatary LK: p53 independent endoplasmic reticulum stress-mediated cytotoxicity of a Newcastle disease virus strain in tumor cell lines. J Virol Doi: 10.1128/JVI.02490-06, 2007.

21. Zeng J, Fournier P and Schirrmacher V: Induction of interferon- $\alpha$ and tumor necrosis factor-related apoptosis-inducing ligand in blood mononuclear cells by hemagglutinin-neuraminidase but not F protein of Newcastle Disease Virus. Virology 297: 19-30, 2002.

22. Fournier P, Zeng J and Schirrmacher V: Two ways to induce innate immune responses in human PBMCs: paracrine stimulation of IFN- $\alpha$ responses by viral protein or dsRNA. Int J Oncol 23: 673-680, 2003.

23. Al-Garib SO, Gielkens AL, Gruys E, Peeters BP and Koch G: Tissue tropism in the chicken embryo of non-virulent and virulent Newcastle diseases strains that express green fluorescence protein. Avian Pathol 32: 591-596, 2003.

24. Schirrmacher V, Haas C, Bonifer R and Ertel C: Virus potentiation of tumor vaccine $\mathrm{T}$ cell stimulatory capacity requires cell surface binding but not infection. Clin Cancer Res 3: 1135-1148, 1997.

25. Reed LJ and Muench H: A simple method of estimating fifty per cent endpoints. Am J Hyg 27: 493-497, 1938.

26. Wise MG, Suarez DL, Seal BS, et al: Development of a realtime reverse-transcription PCR for detection of newcastle disease virus RNA in clinical samples. J Clin Microbiol 42: 329-338, 2004.

27. Pham HM, Konnai S, Usui T, Chang KS, Murata S, Mase M, Ohashi K and Onuma M: Rapid detection and differentiation of Newcastle disease virus by real-time PCR with melting-curve analysis. Arch Virol 150: 2429-2438, 2005.

28. Kasuya H, Kuruppu DK, Donahue JM, Choi EW, Kawasaki H and Tanabe KK: Mouse model of subcutaneous spleen reservoir for multiple portal venous injections to treat liver malignancies. Cancer Res 65: 3823-3827, 2005.

29. Shinozaki K, Ebert O, Kournioti C, Tai YS and Woo SL: Oncolysis of multifocal hepatocellular carcinoma in the rat liver by hepatic artery infusion of vesicular stomatitis virus. Mol Ther 9: 368-376, 2004.

30. Sarraf-Yazdi S, Mi J, Dewhirst MW and Clary BM: Use of in vivo bioluminescence imaging to predict hepatic tumor burden in mice. J Surg Res 120: 249-255, 2004.

31. Russell SJ: RNA viruses as virotherapy agents. (Review). Cancer Gene Ther 9: 961-966, 2002.

32. Nelson NJ: Scientific interest in Newcastle Disease Virus is reviving. J Natl Cancer Inst 91: 1708-1710, 1999.

33. Pecora AL, Rizvi N, Cohen GI, et al: Phase I trial of intravenous administration of PV701, an oncolytic virus, in patients with advanced solid cancers. J Clin Oncol 20: 2251-2266, 2002.

34. Aghi M and Martzua RL: Oncolytic viral therapies-the clinical experience. Oncogene 24: 7802-7815, 2005.

35. Sinkovics JG and Horvath JC: Newcastle disease virus (NDV): brief history of its oncolytic strains. J Clin Virol 16: 1-15, 2000.

36. Meijer J, Zeelenberg IS, Sipos B and Roos E: The CXCR5 chemokine receptor is expressed by carcinoma cells and promotes growth of colon carcinoma in the liver. Cancer Res 66: 9576-9582, 2006.

37. Csatary LK, Moss RW, Beuth J, Torocsik B, Szeberenyi J and Bakacs T: Beneficial treatment of patients with advanced cancer using a Newcastle disease virus vaccine (MTH-68/H). Anticancer Res 19: 635-638, 1999.

38. Horvath CM: Weapons of STAT destruction. Interferon evasion by paramyxovirus V protein. Eur J Biochem 271: 4621-4628, 2004.

39. Park MS, Garcia-Sastre A, Cros JF, Basler CF and Palese P: Newcastle disease virus $\mathrm{V}$ protein is a determinant of host range restriction. J Virol 77: 9522-9532, 2003.

40. Washburn B and Schirrmacher V: Human tumor cell infection by Newcastle disease virus leads to upregulation of HLA and cell adhesion molecules and to induction of interferons, chemokines and finally apoptosis. Int J Oncol 21: 85-93, 2002.

41. Von Hoegen P, Zwatzky R and Schirrmacher V: Modification of tumor cells by a low dose of Newcastle disease virus, III: potentiation of tumor specific cytolytic $\mathrm{T}$ cell activity via induction of interferon $\alpha$, B. Cell Immunol 126: 80, 1990. 
42. Umansky V, Shatrov VA, Lehmann V and Schirrmacher V: Induction of nitric oxide synthesis in macrophages by Newcastle disease virus is associated with activation of nuclear factor- $\kappa \mathrm{B}$. Int Immunol 8: 491-498, 1996.

43. Washburn B, Weigand MA, Grosse-Wilde A, Janke M, Stahl H, Rieser E, Sprick MR, Schirrmacher V and Walczak H: TNFrelated apoptosis-inducing ligand mediates tumoricidal activity of human monocytes stimulated by Newcastle disease virus. J Immun 170: 1814-1821, 2003.

44. Schirrmacher V, Bai L, Umansky V, Yu L, Xing Y and Qian Z: Newcastle disease virus activates macrophages for antitumor activity. Int J Oncol 16: 363-373, 2000.

45. Ertel C, Millar NS, Emmerson PT, Schirrmacher V and von Hoegen P: Viral hemagglutinin augments peptide specific cytotoxic T-cell responses. Eur J Immunol 23: 2592, 1993.

46. Termeer CC, Schirrmacher V, Bröcker EB and Becker JC: Newcastle disease virus infection induces B7-1/B7-2 independent T-cell costimulatory activity in human melanoma cells. Cancer Gene Ther 7: 316, 2000.

47. Bai L, Koopmann J, Fiola C, Fournier P and Schirrmacher V: Dendritic cells pulsed with viral oncolysates potently stimulate autologous T cells from cancer patients. Int J Oncol 21: 685-694, 2002.
48. Phuangsab A, Lorence RM, Reichard KW, Peeples ME and Walter RJ: Newcastle disease virus therapy of human tumor xenografts: antitumor effects of local or systemic administration. Cancer Lett 172: 27-36, 2001.

49. Schirrmacher V, Griesbach A and Ahlert T: Antitumor effects of Newcastle disease virus in vivo: Local versus systemic effects. Int J Oncol 18: 945-952, 2001.

50. Csatary LK, Eckhardt S, Bukosza IF, et al: Attenuated veterinary virus vaccine for the treatment of cancer. Cancer Detect Prev 17: 619-627, 1993.

51. Csatary LK and Bakacs T: Use of Newcastle disease virus vaccine (MTH-68/H) in a patient with high-grade glioblastoma. JAMA 281: 1588-1589, 1999.

52. Hotte SJ, Lorence RM, Hirte HW, et al: An optimized clinical regimen for the oncolytic virus PV701. Clin Cancer Res 13: 977-985, 2007.

53. Demers GW, Johnson DE, Tsai V, et al: Pharmacologic indicators of antitumor efficacy for oncolytic virotherapy. Cancer Res 63: 4003-4008, 2003.

54. Fulci G, Breymann L, Gianni D, et al: Cyclophosphamide enhances glioma virotherapy by inhibiting innate immune responses. Proc Natl Acad Sci USA 103: 12873-12878, 2006. 